\title{
Wood anatomical characters of the Egyptian Tamarix L. species and its taxonomic significance
}

\author{
Nahed M. Waly \\ The Herbarium, Faculty of Science \\ Cairo University, Giza 12613 \\ Egypt.
}

Waly N. M. 1999. Wood anatomical characters of the Egyptian Tamarix L. species and its taxonomic significance. Taeckholmia 19 (2): 115-125.

The secondary xylem elem ents show apparent constancy in their characters among the indiginous species of Tamarix. These characters were studied to evaluate their taxonomic importance. The characters of vessels (width in cross section and number $/ \mathrm{mm}^{2}$ ) were found important at the sectional level, while characters of rays and fiber thikness could be important for the distinction of certain species. Wood anatomical characters were found useful for the identification of Tamarix species when reliable morphological characters such as flowers and fruits are not available. In this respect, such characters would be useful for the identification of archaeological worked, non-worked wood material and charcoal.

Key words: Tamarix, Egypt, wood anatomy, taxonomy.

\section{Introduction}

The genus Tamarix L. comprises about 90 species mostly in the deserts of temperate and subtropical regions of the Old World. These are halophytic shrubs or small quickgrowing trees with scale leaves, minute flowers in dense racemes with nectariferous or non-nectariferous staminal discs (Araffa, 1992).

Willdenow (1816), recognized 16 species of Tamarix among which 7 species were described new. Ehrenberg (1827), was the first to apply the characters of staminal disc and insertion of stamens as important diagnostic characters. This concept was adopted by Bunge (1852), who recognized some 200 binomials. However the recent revision of the genus by Baum (1978) comprised only 54 species.

Täckholm (1974) reported 5 species of Tamarix in Egypt among which Tamarix nilotica, T.passerinoides and T. tetragyna were apparently polymorphic. In her recent revision of Tamarix, Araffa (1991) recognized 8 species which are grouped according to Baum (1978) under three sections. Section Tamarix comprises Tamarix nilotica (Ehrenb.) Bunge, T. mannifera Bunge, T. arborea (Ehrenb.) Bunge and T. aphylla (L.) H. Karst. Section Oligadenia comprises Tamarix tetragyna Ehrenb. while section Polyadenia comprises Tamarix passerinoides Del. ex Desv., T. macrocarpa (Ehrenb.) Bunge and T. amplixecaulis Ehrenb.

In his cheklist to the Flora of Egypt, Boulos (1995:95-96) accepted six of the Tamarix species recognized by Araffa (op.cit). He regarded both of Tamarix mannifera and $T$. arborea as conspecific to T. nilotica.

Received 6 April 1999. Revision accepted 3 November 1999. 
According to Fahn \& Werker (1986:171), the secondary wood of Tamarix species growing in Israel and adjacent regions consists of solitary short vessels (up to $120 \mu \mathrm{m})$ which are storied with parenchyma cells. In vessels, the pits are alternate, rounded slit-like and often with coalescent apertures. The parenchyma are mainly vasicentric and fusiform; rays are wide, up to $1 \mu \mathrm{m}$ or higher.

Zaki et al. (1990) carried out a comparative anatomical study of the young stem and leaf among the Tamarix species of Egypt recognized by Araffa (op.cit). Two anatomical patterns of the young stem (circular and furrowed) were recognized. The anatomical features of these patterns were proved to be significant on the sectional level of Baum's classification (op.cit). The characters of the epidermal cells, the cortical zone and vascular cylinder of the young stem provided reliable characters for the distinction of closely allied species of series Leptostachya of section Tamarix viz. T.nilotica, T. arborea and T. mannifera.

The above prelimenary study shows the necessity of investigating other anatomical characters of the Egyptian Tamarix species which are among the important lignious species. Wood anatomical characters may prove their value in the taxonomy of investigated species.

\section{Materials and Methods}

For each species, woody branches about $1.5 \mathrm{~cm}$ in diameter belonging to selected well identified specimens of the Tamarix species represented in the flora of Egypt (Araffa, 1992) were the subject of the persent study. Attention was paid for studying specimens which were collected from localities representing the geographical range of each species (Table 1).

Wood branches were soaked over night in boiled water before sectioning with a sledge microtome. Sections for examination with light microscope (T.S \& L.S) at 30-50 $\mu$ were stored in an aqueous alcohol-glycerin mixture before double staining with saffranin and light green. Stained sections were dehydrated in alcohol-xylol series, cleared in clove oil and mounted in Canada Balsam. For every speciemen; at least five slides were prepared and examined by light microscope. The measurments given in Tables ( $2 \& 3)$ for the xylem vessels and rays are the means of at least 100 readings using a calibrated occular micrometer.

\section{Results and discussion}

Table (2) presents the wood anatomical characters of Tamarix nilotica, T.aphylla and T. tetragyna which are major constituents of the natural vegetation of the salt marshes (marine and inland), river banks as well as wadi beds of the Eastern and Western Deserts of Egypt. 
Table (1) Examined and anatomically investigated specimens of the Egyptian Tamarix species, (kept in Cairo University Herbarium).

\begin{tabular}{|c|c|}
\hline Species & Specimens \\
\hline Tamarix nilotica & $\begin{array}{l}\text { Ismailia, El Ballah, 16/6/1988, Sh.Araffa. } \\
\text { West salty areas, Bahariya Oasis,16/10/1966, Osborn.. } \\
\text { Aswan, E. Nile, 7/12/1964, L.Boulos. } \\
\text { Kom-Ombo, East salts lands, 19/1/1927, G.Täckholm. } \\
\text { Bab-El Mahmal, Wadi Feiran, Sinai, 13/5/1956, V. Täckholm. } \\
\text { Minia, 1/18/1957, V. Täckholm. } \\
\text { Balouza, North Sinai, 1/5/1976,V. Täckholm. } \\
\text { Wadi Gerawi, Spring 1953, N.El Hadidi. }\end{array}$ \\
\hline Tamarix mannifera & $\begin{array}{l}\text { Kom Aushim, 21/9/1959, V. Täckholm. } \\
\text { Kharga Oasis,5/11/1966, N. El Hadidi. } \\
\text { Wadi Feiran, Sinai, 15/8/1551, V. Täckholm. }\end{array}$ \\
\hline Tamarix arborea & $\begin{array}{l}\text { El Dakhla, Oasis, 15/1/1988, Sh. Araffa. } \\
\text { Hurghada, Safaga road, 22/1/1990. K. El Batanuony. } \\
\text { Sinai, Ain Sokhna,1/1/1988, Sh. Araffa. } \\
\text { South of Giza Pyramids, 1/1/1927, G. Täckholm. }\end{array}$ \\
\hline Tamarix aphylla & $\begin{array}{l}\text { Cairo-Suez Road, near Gebel Ataqa, 25/11/1960, V.T Täckholm. } \\
\text { Sinai, Yamet, 23/9/1988, Sh.Araffa. } \\
\text { Bahariya Oasis, } 11 \mathrm{~km} \text { from Bawiti, 8/3/1979, M. Abdel Ghani. } \\
\text { Bahariya Oasis, Bawiti road, 8/3/1979, M.Abdal Ghani. } \\
\text { Wadi EL Assiuti, 6/12/1962, V. Täckholm. } \\
\text { Red Sea, Wadi Araba, } 10 \mathrm{~km} \text { w. of the road, 7/2/1960, V. Täckholm. }\end{array}$ \\
\hline Tamarix tetragyna & $\begin{array}{l}\text { Nile Delta, } 10 \mathrm{~km} \text { south of Baltim, 18/2/1971, M.Imam. } \\
\text { Salt lands at Gebel Asfar, spring 1958, V. Täckholm. } \\
\text { Ain-Sokhna } 55 \mathrm{~km} \text { south of Suez, 8/5/1953, H.A.F.Gohar. } \\
\text { El-Borollos, Sptember 1952, M.Kassas. } \\
\text { El Heiz, Ain El Ezza, Bahariya, 22/2/1979, M. Abdel Ghani. }\end{array}$ \\
\hline Tamarix passerinoides & $\begin{array}{l}\text { G. Ballah, Ismailia, 30/4/1983, A.M.Amer. } \\
\text { Malhet El- Hamra, Wadi Natroun, 5/2/1968, M.Zahran. }\end{array}$ \\
\hline Tamarix macrocarpa & $\begin{array}{l}\text { Wadi El Farigh, Wadi Natroun, 19/3/1968, M.Zahran. } \\
30 \text { miles South of El Borma, Libyan Desert, 3/4/1965, Osborn \& Helmy. } \\
\text { Kharga Oasis, 10/2/1931, F. W. Oliver. } \\
\text { Wadi El Shooni, } 53 \text { km of Mersa Alam, Red Sea, 92/1961, M. Kassas. }\end{array}$ \\
\hline Tamarix amplexicaulis & $\begin{array}{l}\text { Nubia, Nag el-Dakhla, Ballana, 9/1/1964, L. Boulos. } \\
\text { Near Siwa Town, 26/10/1963, L.Boulos. } \\
\text { Kom Ombo desert, Mouth of Wadi Kharit, 7/12/1964, V. Täckholm. }\end{array}$ \\
\hline
\end{tabular}


It will be noticed (Table 2), that these characters are apparently constant under the adverse environmental conditions. The constancy of the wood anatomical characters among these three species would favour the idea of comparing such charactes with those of the other; less common species of limited geographical range.

Table (2). Wood anatomical characters of the three most common Tamarix species in Egypt.

\begin{tabular}{|c|c|c|c|}
\hline Characters & Tamarix nilotica & Tamarix aphylla & Tamarix tetragyna \\
\hline Number of vessels $/ \mathrm{mm}^{2}$ & $15-20 / \mathrm{mm}^{2}$ & $6-40 / \mathrm{mm}^{2}$ & $6-46 / \mathrm{mm}^{2}$ \\
\hline Vessels diameter & $20-160 \mu \mathrm{m}$ & $30-280 \mu \mathrm{m}$ & $20-140 \mu \mathrm{m}$ \\
\hline Ray width & 6- 10 cells & $10-23$ cells & 6-12 cells \\
\hline Ray height & $1-1.5 \mathrm{~mm}$ & $1-2 \mathrm{~mm}$ & $2 \mathrm{~mm}$ \\
\hline Ray frequency & $2-4 / \mathrm{mm}^{2}$ & $2-3 / \mathrm{mm}^{2}$ & $4 / \mathrm{mm}^{2}$ \\
\hline Wood porosity & $\begin{array}{l}\text { Ring porous-semi ring } \\
\text { porous }\end{array}$ & Diffuse porous & $\begin{array}{l}\text { Ring porous-semi ring } \\
\text { porous }\end{array}$ \\
\hline Fiber thickness & $\begin{array}{l}\text { Thin-medium } \\
1 / 2-1 / 4 \text { lumen }\end{array}$ & $\begin{array}{l}\text { Medium } \\
1 / 2 \text { lumen }\end{array}$ & $\begin{array}{l}\text { Thick } \\
\text { 3/4 lumen }\end{array}$ \\
\hline
\end{tabular}

In Table (3), the investigated Tamarix species are arranged according to the systematic treatment followed by Baum (1978). Three speices viz. Tamarix nilotica, $T$. mannifera and $T$. arborea belong to series Leptostachya of section Tamarix, while $T$. aphylla belongs to series Vaginantes of the same section. The second row comprises Tamarix tetragyna of section Oligadenia, while the third row comprises the species of section Polyadenia, viz. Tamarix passerinoides and T. macrocarpa. The anatomical characters are arranged horizontally according to their systematic value.

Most significant are the characters of vessel number $/ \mathrm{mm}^{2}$ and vessel diameter in cross section. It will be noticed, that vessel diameter is the largest $(20-150 \mu \mathrm{m})$ among the species of series Leptostachya of section Tamarix. They are even wider in Tamarix aphylla of series Vaginantes of the same section. The vessel diameter is apparently narrower among the species of sections Oligadenia and Polyadeniia. However, the vessels of Tamarix tetragyna (section Oligadenia) are wider $(20-140 \mu \mathrm{m})$ than those of the species of section Polyadenia (20-100 $\mu \mathrm{m})$.

Table (3) also shows that the number of vessels $/ \mathrm{mm}^{2}$ ranges between 10-40 vessels $/ \mathrm{mm}^{2}$ among the species of section Tamarix. They are more frequent among the species of sections Oligadenia and Polyadenia. This can be attributed to the vessel's diameter, since the narrower the vessels, the more frequent in a certain area. 
Wood anatomical characters of Egyptian Tamarix

Table (3): Wood anatomical characters of the Tamarix species in Egyp

\begin{tabular}{|c|c|c|c|c|c|c|c|c|}
\hline \multirow{3}{*}{ Characters } & \multicolumn{4}{|c|}{$\begin{array}{l}\text { Sect. } \\
\text { Tamarix }\end{array}$} & \multirow{2}{*}{$\begin{array}{c}\text { Sect. } \\
\text { Oligade } \\
\text { nia } \\
\text { Ser. } \\
\text { Anisandrae }\end{array}$} & \multicolumn{3}{|c|}{$\begin{array}{c}\text { Sect. } \\
\text { Polyadenia }\end{array}$} \\
\hline & \multicolumn{3}{|c|}{$\begin{array}{r}\text { Ser . } \\
\text { Leptostachya }\end{array}$} & \multirow{2}{*}{$\begin{array}{c}\text { Ser. } \\
\text { Vaginantes } \\
\\
\\
T . \\
\text { aphylla }\end{array}$} & & \multicolumn{3}{|l|}{ Pleindrae } \\
\hline & $\begin{array}{cc}9 & T . \\
10 & \text { niloti } \\
& \\
& \mathrm{ca}\end{array}$ & $\begin{array}{l}\text { T. } \\
\text { mannifera }\end{array}$ & $\begin{array}{c}T . \\
\text { arborea }\end{array}$ & & $\begin{array}{c}T . \\
\text { tetragyna }\end{array}$ & $\begin{array}{c}T . \\
\text { passerinoides }\end{array}$ & $\begin{array}{c}T . \\
\text { macrocarpa }\end{array}$ & $\begin{array}{c}T . \\
\text { amplixicaulis }\end{array}$ \\
\hline $\begin{array}{c}\text { Number of } \\
\text { vessels / } \mathrm{mm}^{2}\end{array}$ & $\begin{array}{c}11^{-20-} \\
26 / \mathrm{mm}^{2}\end{array}$ & $\begin{array}{l}10^{-25-30} \\
/ \mathrm{mm}^{2}\end{array}$ & $\begin{array}{c}10^{-22-40} \\
/ \mathrm{mm}^{2}\end{array}$ & $\begin{array}{l}6^{-30-40} \\
/ \mathrm{mm}^{2}\end{array}$ & $\begin{array}{l}6^{-32-46} \\
/ \mathrm{mm}^{2}\end{array}$ & $\begin{array}{c}50^{-56-60} \\
/ \mathrm{mm}^{2}\end{array}$ & $\begin{array}{c}30^{-40-} 65 \\
/ \mathrm{mm}^{2}\end{array}$ & $\begin{array}{c}65^{-68-70} \\
/ \mathrm{mm}^{2}\end{array}$ \\
\hline $\begin{array}{r}\text { Vessel } \\
\text { diameter }\end{array}$ & $\begin{array}{c}20^{-80-} \\
160 / \mathrm{m} \mu\end{array}$ & $\begin{array}{c}30^{-71-} 120 \\
\mathrm{~m} \mu\end{array}$ & $\begin{array}{c}30^{-85-} 125 \\
\mathrm{~m} \mu\end{array}$ & $\begin{array}{c}30^{-102-250} \\
\mathrm{~m} \mu\end{array}$ & $\begin{array}{c}20^{-25,100-} 140 \\
\mathrm{~m} \mu\end{array}$ & $\begin{array}{c}20^{-65-} 110 \\
\mathrm{~m} \mu\end{array}$ & $\begin{array}{c}30^{-68-} 100 \\
\mathrm{~m} \mu\end{array}$ & $\begin{array}{c}30^{-55-90} \\
\mathrm{~m} \mu\end{array}$ \\
\hline Ray height & $1 \mathrm{~mm}$ & $1.5 \mathrm{~mm}$ & $1.5-2 \mathrm{~mm}$ & $1-2 \mathrm{~mm}$ & $<2 \mathrm{~mm}$ & $1.5-2 \mathrm{~mm}$ & $1-2 \mathrm{~mm}$ & $<4 \mathrm{~mm}$ \\
\hline Ray width & $6-10$ cells & 4-8 cells & $3-8$ cells & $5-23$ cells & $5-12$ cells & 8-22 cells & $1-6$ cells & 3-14 cells \\
\hline Ray frequency & $2-4 / \mathrm{mm}^{2}$ & $2-3 / \mathrm{mm}^{2}$ & $2-4 / \mathrm{mm}^{2}$ & $2-3 / \mathrm{mm}^{2}$ & $<4 / \mathrm{mm}^{2}$ & $3-4 / \mathrm{mm}^{2}$ & $2-4 / \mathrm{mm}^{2}$ & $3-4 / \mathrm{mm}^{2}$ \\
\hline $\begin{array}{r}\text { Wood } \\
\text { porosity }\end{array}$ & $\begin{array}{l}\text { ring-semi } \\
\text { ring } \\
\text { porous } \\
\end{array}$ & $\begin{array}{l}\text { diffuse-semi } \\
\text { ring porous }\end{array}$ & $\begin{array}{l}\text { semi ring } \\
\text { porous }\end{array}$ & $\begin{array}{c}\text { diffuse porous } \\
\text {-semi ring } \\
\text { porous } \\
\end{array}$ & $\begin{array}{c}\text { ring porous - } \\
\text { semi ring } \\
\text { porous } \\
\end{array}$ & $\begin{array}{l}\text { ring porous - } \\
\text { semi ring } \\
\text { porous } \\
\end{array}$ & $\begin{array}{l}\text { semi ring } \\
\text { porous }\end{array}$ & $\begin{array}{l}\text { Diffuse } \\
\text { porous }\end{array}$ \\
\hline Fiber thickens & $\begin{array}{l}\text { Medium } \\
1 / 2 \text { lumen }\end{array}$ & $\begin{array}{l}\text { Thick } \\
1 / 4 \text { lumen }\end{array}$ & $\begin{array}{l}\text { Medium } \\
1 / 2 \text { lumen }\end{array}$ & $\begin{array}{l}\text { Thin } \\
\text { 1/4 lumen }\end{array}$ & $\begin{array}{l}\text { Medium } \\
1 / 2 \text { lumen }\end{array}$ & $\begin{array}{c}\text { Thick } \\
3 / 4 \text { lumen }\end{array}$ & $\begin{array}{l}\text { Medium } \\
1 / 2 \text { lumen }\end{array}$ & $\begin{array}{l}\text { Medium } \\
1 / 2 \text { lumen }\end{array}$ \\
\hline $\begin{array}{l}\text { Crystals } \\
\text { in ray }\end{array}$ & Abundant & - & Abundant & Abundant & - & Abundant & - & Abundant \\
\hline
\end{tabular}


The characters of medullary rays (height, width \& frequency) seem to be of moderate systematic value. In section Tamarix, the medullary rays are generally 1-2.5 mm high and are 2-4 rays $/ \mathrm{mm}^{2}$. In species of series Leptostachya, the rays are 4-10-seriate, they are 5-23-seriate in Tamarix aphylla of series Vaginantes. In Tamarix tetragyna (section Oligadenia) the rays are 5-12- seriate, and are 4-22-seriate in species of section Polyadenia.

The other characters, viz. the wood porosity, crystals in rays, and the xylem fiber thickness are of less systematic value and can be used for the distinction of certain species. Wood porosity among the investigated percies is in general semiring- ring porous, it is however liable to be diffuse porous in Tamarix aphylla. The solitary prismatic ray crystals are not observed in Tamarix mannifera, T. tetragyna \& T. macrocarpa. These are of abundant occurrence in the rays of the other species. The wood fibers are apparently thick in Tamarix mannifera and T. passerinoides, thin in T.aphylla and T.tetragyna and are medium - thick in the other investigated species.

The following key, based on wood anatomical characters shows the effeciency of such characters to distinguish between the investigated species of Tamarix.

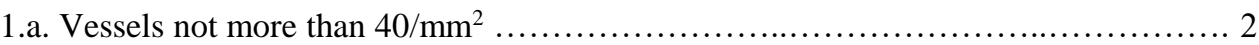

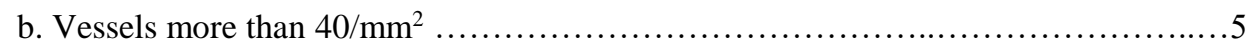

2.a. Rays broad 10-23 cells wide .................................... T. aphylla

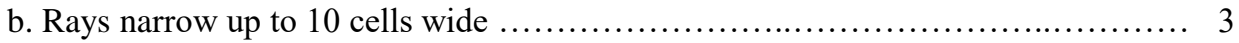

3.a. Crystals absent in rays ........................................ T.mannifera

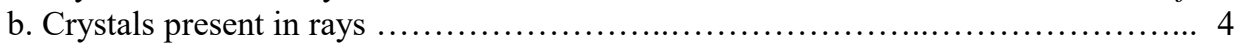

4.a. Rays up to $1 \mathrm{~mm}$ high ........................................... T. nilotica

b. Rays 1.5-2 mm high .................................................. T.

5.a. Rays $2-4 \mathrm{~mm}$ high ........................................ T. amplexicaulis

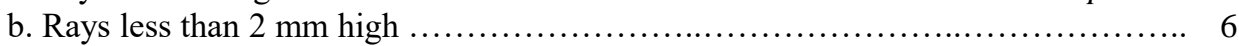

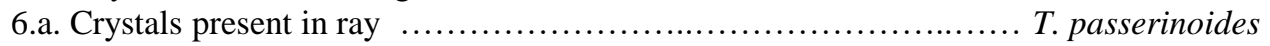

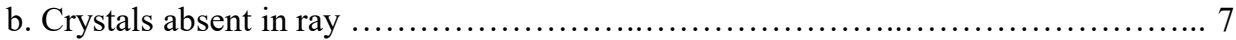

7.a. Rays in L.S up to 6 cells wide .................................. T. macrocarpa

b. Rays in L.S. more than 6 cells wide ............................. T. tetragyna

The above key shows that species of section Tamarix are characterized by wider xylem vessels which are not more than $40 / \mathrm{mm}$. On the other hand, the investigated species of sections Oligadenia and Polyadenia have however vessels which are more than $40 / \mathrm{mm}^{2}$. Next in importance, are the characters of rays including its height, width and presence or absence of crystals. The ray height was useful to distinguish between closely allied species viz. Tamarix nilotica and T. arborea. These are up to $1 \mathrm{~mm}$ high in Tamarix nilotica and 1.5-2 mm high in Tamarix arborea. The rays are narrow (up to 10 cells wide) among the species of series Leptostachya of section Tamarix. They are wider (10-23 cells wide) in Tamarix aphylla of series Vaginates of the same section. It is rather possible to distinguish between T. macrocarpa of section Polyadenia and Tamarix tetragyna of section Olygadenia which show similarities in their anatomical features. The rays are 
narrower (up to 6 cells wide) in T. macrocarpa and broader (more than 6 cells wide) in T. tetragyna.

The present investigation shows that wood anatomical characters are useful in the identification of Tamarix species, when other morphological characters such as flowers and fruits are not available. In this respect, such characters would also be useful for the identification of archaeological worked, non-worked wood material and charcoal (Waly, 1994)

\section{References}

Araffa, Sh. 1992. Taxonomic and ecological study of the species of the genus Tamarix in Egypt. M.Sc Thesis, Botany Department, Faculty of Science, Cairo University.

Baum, B. 1978. The genus Tamarix. Israel Academy of Sciences.

Boulos, L. 1995. Flora of Egypt Checklist, Al Hadara publishing, Cairo Egypt.

Bunge, A. von. 1851. Alexandri Lehman Reliquiae Botanicae. Mém. Acad. St. Petersb. 7:290- 296

Ehrenberg, C.G. 1827. Über die Manna-Tamarisks nebst allgemeinen Bemerkungen uber dieTamarisceen, Linnaea, 2:241-344.

Fahn, A. 1986. Wood Anatomy and Identification of Trees and Shrubs from Israel and Adjacent Reigon. Jerusalem.

Täckholm,V. 1974. Students Flora of Egypt, ed. 2:336-367.

Waly, N.M. 1994, Documetary and Comparative Anatomical study of the wood and charcoal plants of ancient Egypt. Ph.D Thesis, BotanyDepartment, Faculty of Science, Cairo University.

Zaki, M. A.; Hosni, H. A. \& Araffa, S. 1991. Morphological and anatomical features of species of Tamarix in Egypt. Egypt. J. Appl. Sci. 6(10):502-511. 


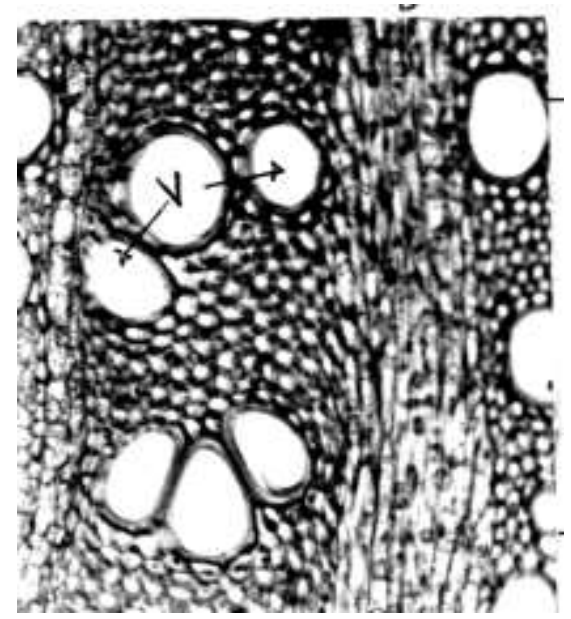

T.S. in Tamarix nilotica (x125), showing vessels $(\mathrm{V})$ ring to semi-ring porous, vessels diameter $20-160 \mathrm{~m} \mu$; vessels frequency $11-26 / \mathrm{mm}^{2}$

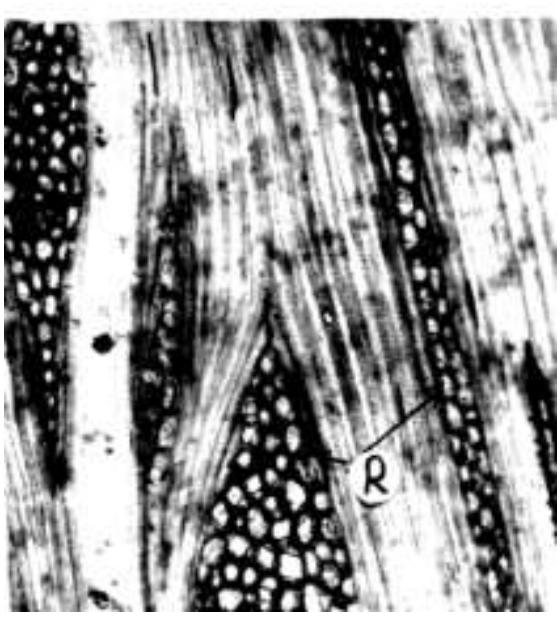

L.S. in Tamarix nilotica (x125), showing ray (R) 1-2 mm high, ray width $6-10$ cells; ray frequency $2-4 / \mathrm{mm}^{2}$

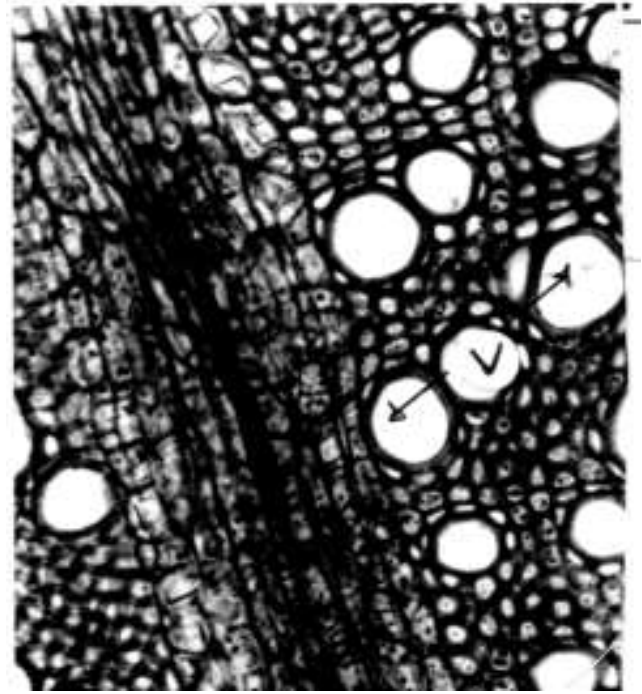

T.S. in Tamarix aphylla (x125),

showing vessels (V) difuse to semi-ring porous, vessels diameter $30-280 \mathrm{~m} \mu$; vessels frequency $6-40 / \mathrm{mm}^{2}$

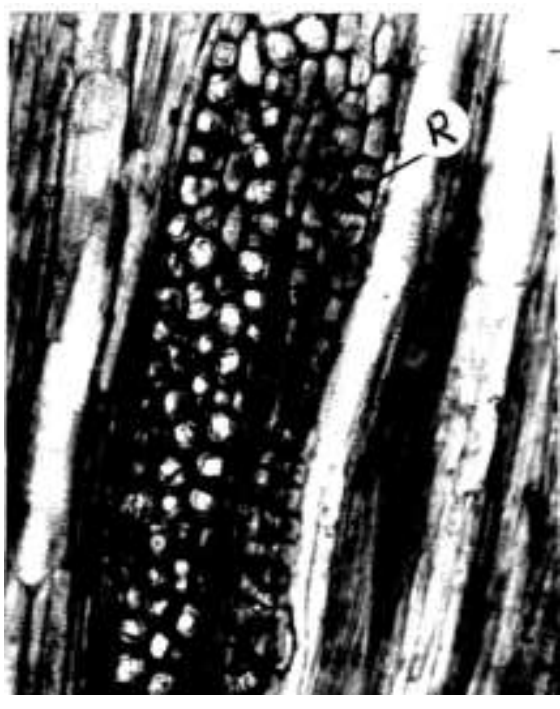

L.S. in Tamarix aphylla (x125), showing ray (R) 1-2 mm high, ray width 5-23 cells; ray frequency $2-4 / \mathrm{mm}^{2}$ 


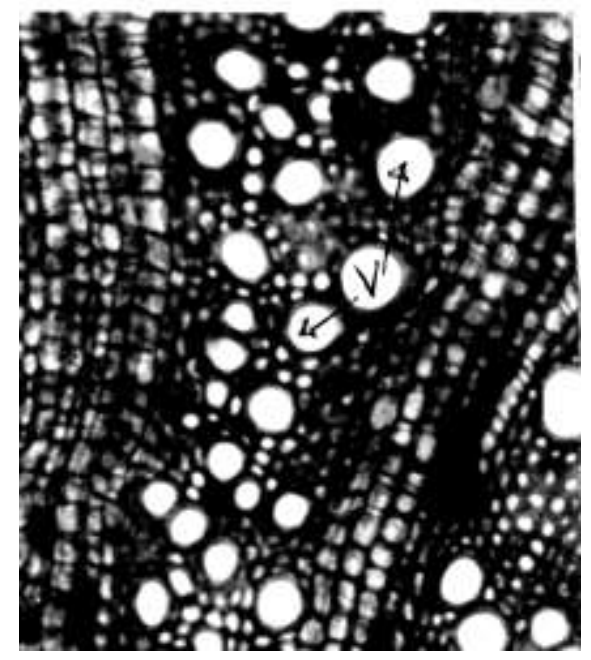

T.S. in Tamarix passerinoides (x125), showing vessels $(\mathrm{V})$ ring to semi-ring porous, vessels diameter $20-110 \mathrm{~m} \mu$; vessels frequency $3-4 / \mathrm{mm}^{2}$.

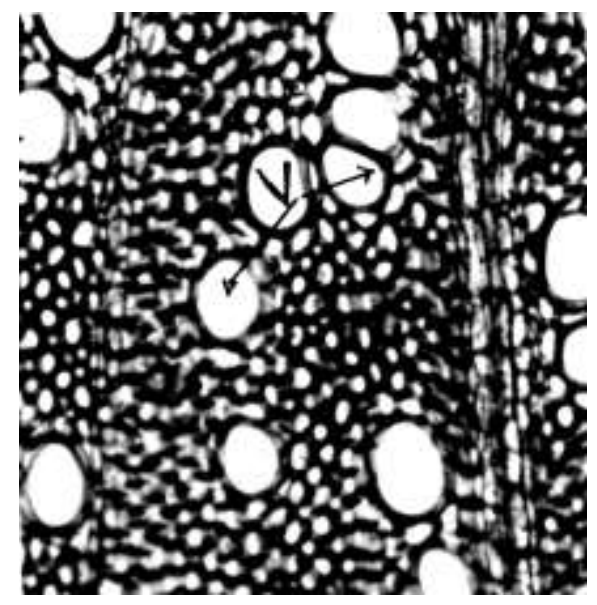

T.S. in Tamarix macrocarpa (x125), showing vessels $(\mathrm{V})$ semi-ring porous, vessels diameter 30-100 $\mathrm{m} \mu$; vessels frequency $30-65 / \mathrm{mm}^{2}$

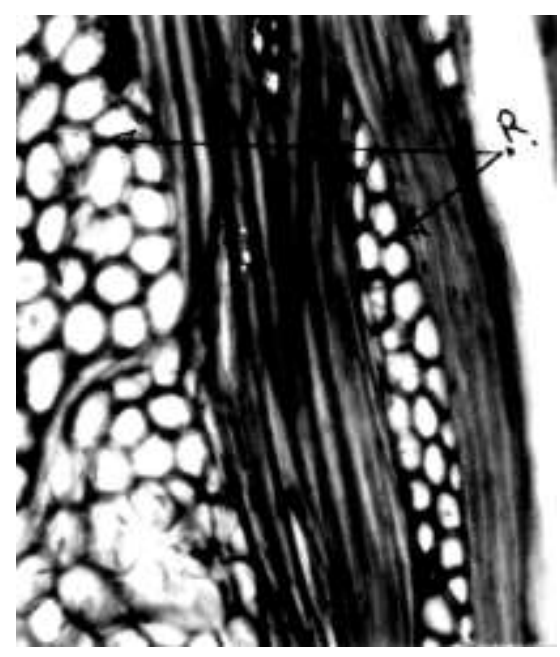

L.S. in Tamarix passerinoides (x125), showing ray (R) $1.5-2 \mathrm{~mm}$ high, ray width 5-23 cells; ray frequency 50$60 / \mathrm{mm}^{2}$.

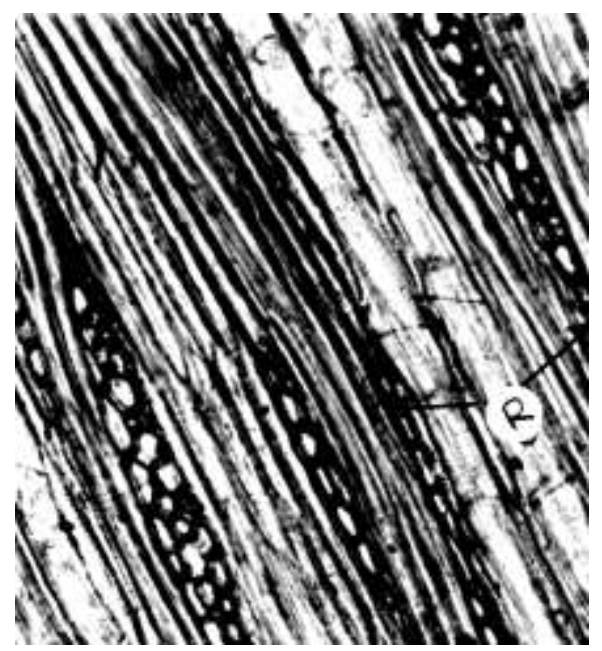

L.S. in Tamarix macrocarpa (x125), showing ray (R) 1-2 mm high, ray width $1-16$ cells; ray frequency $2-4 / \mathrm{mm}^{2}$ 


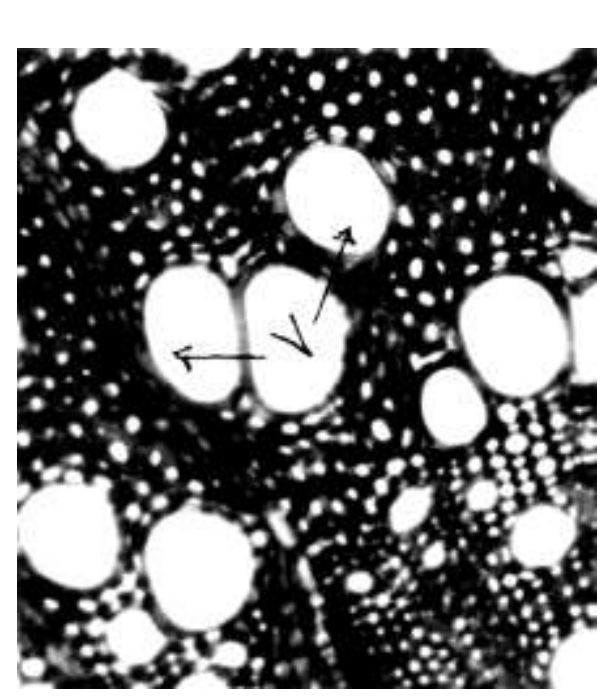

T.S. in Tamarix tetragyna (x125), showing vessels $(\mathrm{V})$ ring to semi-ring porous, vessels diameter $20-140 \mathrm{~m} \mu$; vessels frequency $6-46 / \mathrm{mm}^{2}$

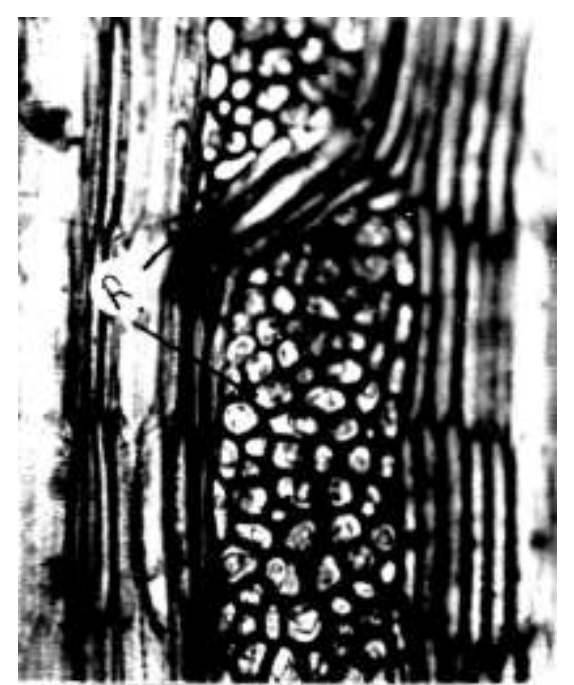

L.S. in Tamarix tetragyna (x125), showing ray $(\mathrm{R})<2 \mathrm{~mm}$ high, ray width $5-12$ cells; ray frequency $<4 / \mathrm{mm}^{2}$

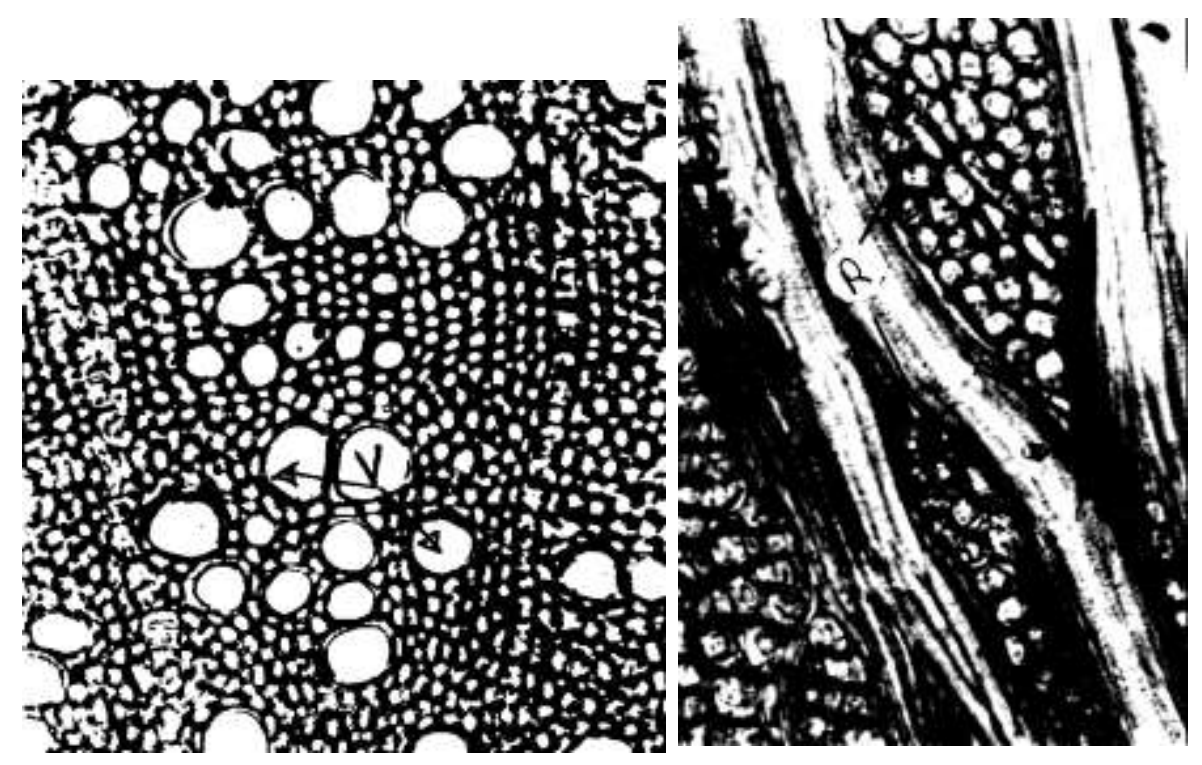

T.S. in Tamarix amplexicaulis (x125), showing vessels $(\mathrm{V})$ difuse porous, vessels diameter 30-90 $\mathrm{m} \mu$; vessels frequency $65-70 / \mathrm{mm}^{2}$
L.S. in Tamarix amplexicaulis (x125), showing ray $(\mathrm{R})<4 \mathrm{~mm}$ high, ray width 1-14 cells; ray frequency 3 $4 / \mathrm{mm}^{2}$ 


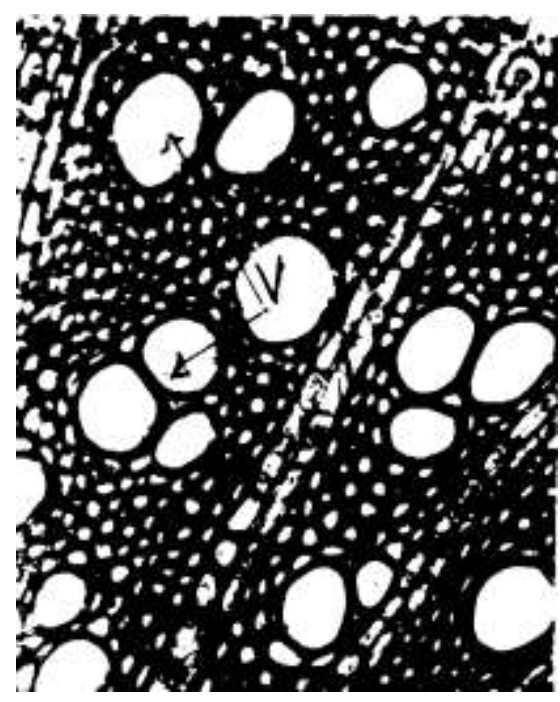

T.S. in Tamarix mannifera (x125), showing vessels $(\mathrm{V})$ difuse to semi-ring porous, vessels diameter $30-120 \mathrm{~m} \mu$; vessels frequency $3-4 / \mathrm{mm}^{2}$

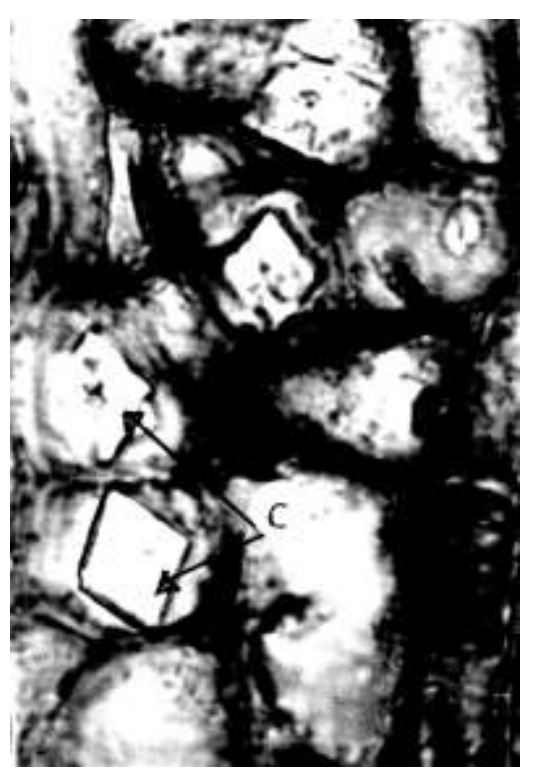

L.S. in Tamarix aphylla (x125), showing abundant solitary crystals (C) in rays.

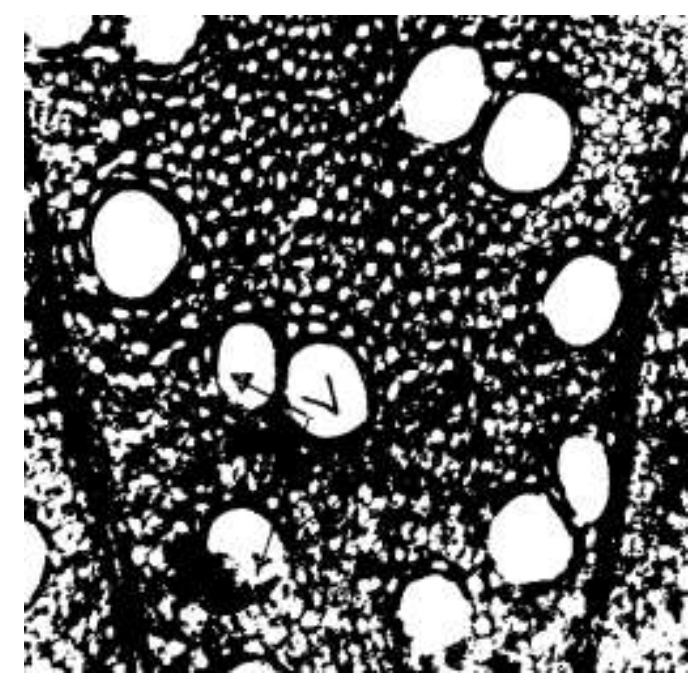

T.S. in Tamarix arborea (x125),

showing vessels (V) semi-ring porous, vessels diameter 30-125 $\mathrm{m \mu}$; vessels frequency $10-40 / \mathrm{mm}^{2}$ 